\title{
PENINGKATAN KECERDASAN VISUAL SPASIAL MELALUI KEGIATAN KOLASE BERBASIS SAINTIFIK DI TK AISYIYAH KOTA MAKASSAR
}

\author{
Muhlisah $^{1}$ \& Herlina ${ }^{2}$ \\ ${ }^{12}$ Pendidikan Guru Pendidikan Anak Usia Dini, Universitas Negeri Makassar
}

\begin{abstract}
:
The research objective was to determine the increase Visual Spatial Intelligence child through activities based on scientific collage B1 group of kindergarten Aisyiyah Middle Maccini Makassar. The approach used in this study is a qualitative approach to the type of research is classroom action research. These research subjects are 16 childrens and one teacher. The technique of collecting data through observation, testing and documentation. The results showed that visual-spatial intelligence in cycle 1 the first meeting has not developed as visual-spatial intelligence of children has not increased, in cycle 1 meeting II has been a change but still lacking for visual-spatial intelligence has not reached the standard to be achieved. In the second cycle the first meeting children's visual-spatial intelligence have been increased, the second cycle II meeting has been increased to better than that, teachers and students activities also increased category is very good. Conclusion of the study is improvement of visual-spatial intelligence through scientific-based collage BI group of kindergarten Aisiyah Middle Maccini Makassar City is said to increase.
\end{abstract}

Keywords: Visual spatial, kindergarten, child

\begin{abstract}
Abstrak:
Tujuan penelitian adalah untuk mengetahui peningkatan Kecerdasan Visual Spasial anak melalui kegiatan kolase berbasis saintifik kelompok B1 Taman Kanak-kanak Aisyiyah Maccini Tengah Kota Makassar. Pendekatan yang digunakan pada penelitian ini yaitu pendekatan kualitatif dengan jenis penelitian yang digunakan adalah penelitian tindakan kelas. Subjek penelitian ini berjumlah 16 anak dan 1 guru. Teknik pengumpulan data melalui teknik observasi, tes dan dokumentasi. Hasil penelitian menunjukan bahwa kecerdasan visual spasial pada siklus 1 pertemuan I belum berkembang karena kecerdasan visual spasial anak belum meningkat, pada siklus 1 pertemuan II sudah ada perubahan namun masih kurang karena kecerdasan visual spasial belum mencapai standar yang ingin dicapai. Pada siklus II pertemuan I kecerdasan visual spasial anak sudah mengalami peningkatan, siklus II pertemuan II sudah mengalami peningkatan dengan baik selain itu, guru dan aktifitas anak didik juga mengalami peningkatan dikategoriikan sangat baik. Kesimpulan hasil penelitian yaitu peningkatan kecerdasan visual spasial melalui kegiatan kolase berbasis saintifik kelompok B1 Taman Kanak-kanak Aisiyah Maccini Tengah Kota Makassar dikatakan meningkat.
\end{abstract}

Kata Kunci: Visual spasial, taman kanak-kanak, anak 


\section{PENDAHULUAN}

Pendidikan pada usia dini merupakan wahana pendidikan awal dalam memberikan kerangka dasar terhadap perkembangan pengetahuan, sikap dan keterampilan pada anak. Menurut Sujiono (2009) mengatakan bahwa pendidikan anak usia dini pada dasarnya meliputi seluruh upaya dan tindakan yang dilakukan oleh pendidik dan orang tua dalam proses perawatan dan pengasuhan terhadap pertumbuhan dan perkembangan anak dimana anak dapat mengeksplorasi pengalaman serta kesempatan yang diperoleh dari lingkungan melalui beberapa cara seperti mengamati, meniru dan bereksperimen yang berlangsung secara berulang-ulang dan melibatkan seluruh potensi dan kecerdasan anak. Pendidikan anak usia dini dalam hal ini memiliki rentang usia mulai dari 0 sampai 6 tahun. Menurut Undang-Undang No.20 Tahun 2003 tentang sistem pendidikan Nasional Bab 1, pasal 1, Butir 14 menyatakan bahwa :

Pendidikan anak usia dini adalah suatu upaya pembinaan yang ditujukan kepada anak sejak lahir sampai dengan usia enam tahun yang dilakukan melalui pemberian rangsangan pendidikan untuk membantu pertumbuhan dan perkembangan jasmani dan rohani agar anak memiliki kesiapan dalam memasuki pendidikan lebih lanjut.

Sesuai dengan peraturan perundang-undangan di atas maka pendidikan anak usia dini sangat sesuai dijadikan sebagai tempat atau wadah pengembangan kecerdasan anak. Menurut Asmani (2015) kecerdasan atau intelegensi sangat penting bagi kehidupan seseorang. Sebab, tanpa intelegensi tersebut seseorang tidak akan mampu membedakan baik itu hal nyata maupun yang tidak. Intelegensi atau kecerdasan berkembang melalui proses pembelajaran. Jika kecerdasan tidak diasah maka kecerdasan tersebut tidak akan berkembang dan tidak akan mengalami perubahan pada diri orang tersebut. Kecerdasan atau intelegensi tidak hanya terpaut pada kecerdasan individual, namun juga kecerdasan majemuk. Kecerdasan majemuk atau Multiple intelligences menurut Asmani (2015: 160) "suatu kemampuan ganda untuk memecahkan suatu masalah yang dihadapi dalam kehidupan". Hal tersebut menjelaskan bahwa seseorang mampu menghadapi apapun masalah yang ada pada kehidupannya tersebut dengan menggunakan kecerdasankecerdasan yang ada pada diri seorang tersebut. Sehingga Yaumi \& Ibrahim (2013) mengemukakan bahwa Gadner menemukan delapan kecerdasan yang ada pada diri manusia, yaitu kecerdasan verbal- matematik, visual-spasial, berirama-musik, jasmaniahkinestetik, interperonal, intrapersonal, dan naturalistik.

Kecerdasan yang akan dibahas dalam penelitian ini adalah Kecerdasan visual spasial, yaitu merupakan kercerdasan yang dikaitkan dengan bakat seni lukis dan arsitektur. Kecerdasan visual-spasial menurut Subianto (2004: 40) merupakan "kemampuan visualisasi secara akurat bentuk, bangun, ruang dan warna". Kecerdasan visual spasial harus dirangsang dengan baik. Jika tidak, maka kecerdasan visual spasial tidak akan berkembang dengan optimal. Berdasarkan observasi yang dilakukan tanggal 18 - 20 Januari 2016 di Taman Kanak-kanak Aisiyah Maccini Tengah Kota Makassar Kelompok B1, pada observasi hari pertama pada tanggal 18 januari 2016 Pada saat guru menjelaskan materi mengenai kegiatan kolase guru hanya memberikan informasi yang berkaitan dengan bagaimana membuat kolase tanpa memberikan contoh karya kolase kepada anak dan media yang digunakan pun masih kurang variatif hal tersebut mengakibatkan 
kecerdasan visual spasial anak masih kurang hal tersebut dapat dilihat dari kepekaan anak dalam mengenal warna, bentuk, ukuran, pola, sifat, suara, tekstur, fungsi, dan ciri-ciri lainnya. Observasi hari kedua pada tanggal 19 januari 2016 ketika anak bermain balok anak hanya mampu menyusun ke atas dan ke samping hal tersebut menandakan bahwa kecerdasan visual spasialnya masih kurang seperti yang diketahui bahwa dalam kecerdasan visual spasial anak di usia tersebut sudah mampu mengenal arah baik itu samping keatas kebawah dan sebagainnya. Penyebab lain dari hal tersebut dapat dilihat dari teknik mengajar yang masih kurang kreatif oleh guru. Observasi akhir atau observasi hari ketiga pada tanggal 20 januari 2016 ketika kegiatan menggambar orang, anak hanya mampu membuat coretan sederhana berupa garis, lingkaran dan titik padahal kecerdasan ini mengacu pada pengertian yang tepat tentang ruang, visualisasi, dan kemampuan terhadap kepekaan warna, garis dan juga bentuk yang dapat mempermudah menemukan arah dengan cepat. Sehubungan dengan hal tersebut, dapat digambarkan bahwa kecerdasan visual spasial anak di Taman Kanak-kanak Aisiyah Maccini Tengah Kota Makassar masih kurang. Hal ini karena anak tidak diberikan aktivitas yang membuatnya mengenal materi secara langsung. Kolase merupakan salah satu kegiatan membentuk yang dapat mengembangkan fungsi otak dan rasa. keterampilan ini memerlukan koordinasi mata, tangan, dan rasa yang dimotori oleh kinerja otak.

Qomariyah \& Setyowati (2016) mengemukakan bahwa kolase merupakan perkembangan lebih lanjut dari seni lukis. Karya seni kolase mengedepankan nilai dasar keindahan, tata penyusunan objek, kontur, bentuk objek dan warna. Pendapat lain juga dikemukakan oleh Nurhadiat (2005: 8) bahwa kolase adalah kegiatan membuat gambar dengan cara menempelkan benda tipis dan lebar setelah dibentuk terlebih dahulu. Kecerdasan visual spasial dapat berkembang ketika anak mengumpulkan dan mengordinisir skemata sebagai pengetahuan untuk dapat mengidentifikasi material kolase. Skemata tersebut diperoleh dari pengamatan yang cermat. Oleh karena itu, dibutuhkan suatu metode pembelajaran yang tepat untuk membantu anak mengembangkan kecerdasan visual spasialnya secara langsung dan menjawab rasa ingin tahu anak. Dalam penelitian ini pembelajaran yang digunakan peneliti yaitu pembelajaran yang berbasis saintifik.

Menurut Sani (2015) Pendekatan saintifik atau pendekatan berbasis proses keilmuan berdasarkan teori Dyer dalam pembelajaran memiliki empat komponen proses pembelajaran antara lain : 1) Mengamati; 2) Menanya; 3) Mencoba/mengumpulkan informasi; 4) menalar/ asosiasi, membentuk jejaring (melakukan komunikasi). Berdasarkan rumusan masalah di atas, yang menjadi tujuan dari penelitian ini adalah untuk mengetahui peningkatan kecerdasan visual spasial anak melalui kegiatan kolase berbasis saintifik di kelompok B1 Taman Kanak-kanak Aisyiyah Maccini Tengah Kota Makassar.

\section{METODOLOGI}

Pendekatan penelitian yang digunakan dalam penelitian ini yaitu pendekatan kualitatif. Penelitian ini berusaha mendeskripsikan hal yang berhubungan dengan peningkatan kecerdasan visual spasial anak kelompok B1 di Taman Kanak-kanak Aisiyah Maccini Tengah Kota Makassar. Jenis penelitian yang dilakukan adalah Penelitian Tindakan Kelas. Dimana penelitian tindakan kelas berasal dari istilah bahasa inggris yakni Classroom Action Research. Subjek dalam penelitian ini adalah anak yang berada di 
kelompok B1 di TK Aisiyah Maccini Tengah Kota Makassar dengan jumlah anak sebanyak 16 orang dan jumlah guru yang diteliti 1 orang. Teknik yang digunakan dalam penelitian ini adalah analisis kualitatif. Analisis data dalam penelitian kualitatif dilakukan sebelum memasuki lapangan, selama di lapangan dan setelah selesai di lapangan. Miles dan Huberman (Iskandar, 2012) mengemukakan bahwa analisis kualitatif dapat dilakukan dengan cara:

a. Reduksi data

Reduksi data merupakan proses pengumpulan data penelitian, seorang peneliti dapat menemukan kapan saja waktu untuk mendapatkan data yang banyak, apabila peneliti mampu menerapkan metode observasi, wawancara atau dari pada tahap ini, peneliti harus mampu merekam data lapangan dalam bentuk catatan-catatan lapangan (fils note), harus ditasfirkan atau diseleksi masing-masing data yang relevan dengan fokus masalah yang diteliti.

b. Melaksanakan display data atau penyajian data

Penyajian data kepada yang telah diperoleh kedalam sejumlah matriks atau daftar kategori setiap data yang didapat, penyajian data biasanya digunakan berbentuk teks naratif, biasanya dalam penelitian, kita mendapat data yang banyak. Data yang kita dapat tidak mungkin paparkan secara keseluruhan.

c. Mengambil kesimpulan atau verifikasi

Mengambil kesimpulan merupakan analisis lanjutan dari reduksi data, dan display data sehingga data dilapangan, dengan cara merefleksi kembali, peneliti masih berpeluang untuk menerima masukan. Penarikan kesimpulan sementara, masih dapat diuji kembali dengan data lapangan, dengan cara merefleksi kembali, peneliti dapat bertukar pikiran dengan teman sejawat sehingga kebenaran ilmiah dapat tercapai.

Penelitian ini dikatakan behasil jika dalam proses pembelajaran guru mampu menjalankan langkah-langkah kegiatan kolase berbasis saintifik sesuai dengan langkahlangkah yang telah ditetapkan dan jika hasil pengamatan menunjukkan $85 \%$ dari seluruh aspek yang diamati telah memenuhi kriteria baik. Apabila terjadi peningkatan kecerdasan visual spasial anak setelah diterapkan kegiatan kolase berbasis saintifik apabila $75 \%$ anak didik berada pada kategori berkembang.

\section{HASIL DAN PEMBAHASAN}

\section{Perencanaan}

Sebelum peneliti melaksanakan kegiatan pembelajaran, terlebih dahulu peneliti berdiskusi dengan guru kelompok B1 untuk menyusun rancangan pelaksanaan pembelajaran harian yang berkaitan dengan kecerdasan visual spasial anak melalui kegiatan kolase yang berbasis saintifik Adapun langkah-langkah yang peneliti lakukan di Taman Kanak-kanak Aisiyiyah Maccini Tengah Kota Makassar pada pembelajaran dan tahap perencanaan ini yang meliputi:

a. Membuat Rencana Pelaksanaan Pembelajaran Harian (RPPH)

Pada kegiatan ini guru dan observer (peneliti) membuat atau menyusun Rancangan pelaksanaan pembelajaran harian yang akan di lakukan dalam proses belajar mengajar. Rencana pelaksanaan pembelajaran harian dengan tema diriku dan sub tema tubuhku yang 
terbagi atas empat kegiatan yaitu kegiatan awal, kegiatan inti, kegiatan istirahat, dan kegiatan akhir (penutup).

b. Membuat skenario pembelajaran

Peneliti dan guru mempersiapkan skenario kemampuan kecerdasan visual spasial melalui kegiatan kolase berbasis saintifik. Skenario ini berisi tata cara atau langkahlangkah kegiatan kolase dalam upaya meningkatkan kecerdasan visual spasial anak didik. Sehingga pada saat pelaksanaan kegiatan dapat berlangsung sesuai dengan harapan yang ingin dicapai.

c. Mempersiapkan media yang akan digunakan dalam pembelajaran

Peneliti dan guru mempersiapakan media yang akan digunakan dalam pembelajaran nantinya yaitu media kolase yang sesuai dengan tema dan sub tema yang akan di ajarkan. d. Menyiapkan instrumen atau lembar observasi

Dalam kegiatan ini guru dan observer (peneliti) terlebih dahulu menyiapkan format observasi untuk melihat aktivitas anak didik dan guru selama kegiatan berlangsung. Dimana peneliti sebagai observer dan guru sebagai pengajar. Format observasi ini berisi hal-hal yang akan di amati pada saat kegiatan berlangsung. Selain itu peneliti juga akan melihat aktivitas yang dilakukan oleh guru di taman kanak-kanak Aisiyiyah Maccini Tengah Kota Makassar pada kegiatan kolase berbasis saintifik anak pada kelompok B1.

\section{Pelaksanaan Pembelajaran}

Pertama-tama membaca doa sebelum belajar kemudian guru menjelaskan apa yang akan dilaksanakan pada hari ini . fokus pada penelitian ini yaitu kecerdasan visual spasial dengan indikator kepekaan mengenal warna, garis, bentuk, ruang dan bangunan. Kegiatan yang dilakukan anak yaitu kolase gambar tubuh anak sekolah menggunakan kepingankepingan kertas warna-warni dan dapat dilihat pada langkah-langkah berikut ini :

Guru menyiapkan alat dan bahan seperti pola gambar yang akan diisi dengan kepingan kolase, lem, kertas warna dan bahan lainnya, guru membagi anak dalam kelompok kecil yang dalam satu kelompok terdiri dari 3-4 anak. Guru membagikan alat dan bahan yang akan digunakan untuk kegiatan kolase kepada anak dengan tertib. Guru memperkenalkan satu-persatu alat dan bahan yang akan digunakan kemudian memperlihatkan contoh kolase.

Selanjutnya, guru memperlihatkan cara mengerjakan kolase sepeti cara memberi lem pada kepingan kolase yang telah disediakan, dan cara menempel kepingan kolase pada pola gambar yang disediakan, mempersilahkan anak untuk untuk melaksanakan kegiatan kolase, dan memberi motivasi kepada anak untuk bekerja sesuai dengan imajinasinya sendiri dan mengamati proses pekerjaan dan hasil pekerjaan anak dan memberikan kesempatan untuk berpendapat dan bertanya.

\section{Hasil Obsevasi}

a. Hasil Observasi Guru Siklus I

- Guru menyiapkan alat dan bahan seperti pola gambar yang akan diisi dengan kepingan kolase, lem dan bahan lainnya. Langkah awal yang dilakukan guru yaitu menyiapkan alat dan bahan diperlukan saat proses belajar yang akan diselesaikan anak. Pada langkah ini guru berada dalam kategori cukup karena guru masih 
memerlukan bantuan dalam menyiapkan alat dan bahan yang di perlukan saat proses belajar.

- Guru membagi anak dalam kelompok kecil yang dalam satu kelompok terdiri dari 3-4 anak. Pada langkah ini guru berada pada kategori cukup karena guru masih memerlukan bantuan untuk membagi anak dalam satu kelompok dengan jumlah anak sebanyak 3-4 orang.

- Guru membagikan alat dan bahan yang akan digunakan untuk kegiatan kolase kepada anak dengan tertib. Sebelum menjelaskan kegiatan kepada anak guru terlebih dahulu harus membagikan alat dan bahan kepada anak. Pada langkah ini guru berada pada kategori kurang karena masih kurang mampu membagikan alat dan bahan yang akan digunakan.

- Guru memperkenalkan satu-persatu alat dan bahan yang akan digunakan. Pada langkah ini guru masih berada dalam kategori kurang, dilihat dari cara memperkenalkan satu persatu alat dan bahan yang akan digunakan masih kurang.

- Guru memperlihatkan contoh kolase. Dalam memperlihatkan contoh kolase anak berada pada kategori baik.

- Guru memperlihatkan cara mengerjakan kolase sepeti cara memberi lem pada kepingan kolase yang telah disediakan, dan cara menempel kepingan kolase pada pola gambar yang disediakan. Pada langkah ini guru masih berada pada kategori kurang.

- Guru mempersilahkan anak untuk melaksanakan kegiatan kolase, dan memberi motivasi kepada anak untuk bekerja sesuai dengan imajinasinya sendiri. pada langkah ini guru berada pada kategori kurang karena masih kurang mampu memotivasi anak untuk bekerja sesuai dengan imajinasinya sendiri.

- Guru mengamati proses pekerjaan dan hasil pekerjaan anak dan memberikan kesempatan untuk berpendapat dan bertanya. Masih pada kategori kurang karena masih belum mampu mengamati proses pekerjaan dan hasil pekerjaan serta belum mampu memberikan kesempatan untuk berpendapat dan bertanya.

b. Hasil Observasi Guru Siklus II

- Pada langkah pertama siklus I pertemuan II guru tetap menyiapkan alat dan bahan seperti pola gambar yang akan di isi dengan kepingan kolase, lem dan bahan lainnya. Pada langkah ini guru berada dalam kategori baik karena guru mampu dalam menyiapkan alat dan bahan yang di perlukan saat proses belajar hanya saja belum sesuai urutan.

- Guru membagi anak dalam kelompok kecil yang dalam satu kelompok terdiri dari 3-4 anak. Pada langkah ini guru berada pada kategori sangat baik karena telah mampu membagi anak dalam satu kelompok dengan jumlah anak sebanyak 3-4 orang dengan baik dan benar sesuai urutan.

- Guru membagikan alat dan bahan yang akan digunakan untuk kegiatan kolase kepada anak dengan tertib. Sebelum menjelaskan kegiatan kepada anak guru terlebih dahulu harus membagikan alat dan bahan kepada anak. Pada langkah ini guru berada pada kategori baik karena telah mampu membagikan alat dan bahan yang akan digunakan meski belum sesuai urutan. 
- Guru memperkenalkan satu-persatu alat dan bahan yang akan digunakan. Pada langkah ini guru berada dalam kategori cukup, dilihat dari cara memperkenalkan satu persatu alat dan bahan yang akan digunakan sudah baik dan benar tetapi masi belum sesuai urutan dan memerlukan bantuan.

- Guru memperlihatkan contoh kolase. Dalam memperlihatkan contoh kolase anak berada pada kategori sangat baik.

- Guru memperlihatkan cara mengerjakan kolase sepeti cara memberi lem pada kepingan kolase yang telah disediakan, dan cara menempel kepingan kolase pada pola gambar yang disediakan. Pada langkah ini guru masih berada pada kategori cukup.

- Guru mempersilahkan anak untuk melaksanakan kegiatan kolase, dan memberi motivasi kepada anak untuk bekerja sesuai dengan imajinasinya sendiri. pada langkah ini guru berada pada kategori baik karena mampu memotivasi anak untuk bekerja sesuai dengan imajinasinya sendiri dengan baik dan benar tetapi belum sesuai urutan.

- Guru mengamati proses pekerjaan dan hasil pekerjaan anak dan memberikan kesempatan untuk berpendapat dan bertanya. kategori cukup karena masih belum mampu mengamati proses pekerjaan dan hasil pekerjaan serta belum mampu memberikan kesempatan untuk berpendapat dan bertanya dengan baik dan benar tidak sesuai urutan dan masih memerlukan bantuan.

c. Hasil Observasi Anak Siklus I

- Pada indikator menempel gambar sesuai warna. Pada kategori berkembang (B) dari 16 anak, ada 3 orang anak yaitu SHF, A.Z dan M.Z karena mampu mampu menempel gambar sesuai warna. Pada kategori mulai berkembang (MB) ada 3 orang anak yaitu FA, GF dan NVL karena sudah mampu menempel sesuai warna meski masih dengan bantuan guru. Pada kategori belum berkembang (BB) terdapat 10 orang anak yaitu IN, KE, FRS, NL,INY, HK, AML, KM, AQ , dan HF Karena sama sekali tidak mampu menempel sesuai warna pada pada saat melakukan kegiatan kolase.

- Pada indikator menempel dengan mengikuti garis pola. Pada kategori berkembang (B) dari 16 orang anak, ada 3 orang anak yaitu SHF, GF dan A.Z karena mampu menempel dengan mengikuti garis pola . Pada kategori mulai berkembang (MB) ada 3 orang anak yaitu FA, M.Z dan NVL karena sudah mampu menempel mengikuti garis pola tetapi meski masih dalam bantuan guru. Pada kategori belum berkembang (BB) ada 10 orang anak yaitu IN, KE, FRS, NL, INY, HK, AML, KM, AQ dan HF karena sama sekali tidak mampu menempel mengikuti garis pola gambar tubuh anak sekolah.

- Pada indikator menempel sesuai bentuk pola gambar. Pada kategori berkembang (B) dari 16 orang anak, ada 2 orang anak yaitu SHF, A.Z, karena mampu menempel sesuai bentuk pola gambar. Pada kategori mulai berkembang (MB) ada 4 orang anak yaitu FA, GF, M.Z dan NVL karena sudah mampu menempel sesuai bentuk pola tetapi masih dalam bantuan guru. Pada kategori belum berkembang (BB) ada 10 orang anak yaitu IN, KE, FRS, NL, INY, HK, AML,A.Z, KM, AQ dan HF karena sama sekali tidak mampu menempel sesuai bentuk pola gambar. 
Pada indikator menempel gambar pola bangunan yang belum lengkap. Pada kategori berkembang (B) dari 16 orang anak, ada 1 orang anak yaitu SHF karena mampu menempel gambar pola bangunan yang belum lengkap. Pada kategori mulai berkembang (MB) ada 4 orang anak yaitu FA, GF, M.Z dan NVL karena sudah mampu menempel gambar pola bangunan yang belum lengkap tetapi masih dalam bantuan guru. Pada kategori belum berkembang (BB) ada 11 orang anak yaitu IN, KE, FRS, NL, INY, HK, AML, A.Z, KM, AQ dan HF karena sama sekali tidak mampu menempel gambar pola bangunan yang belum lengkap.

d. Hasil Observasi Anak Siklus II

- Pada indikator menempel gambar sesuai warna. Pada kategori berkembang (B) dari 16 anak, ada 4 orang anak yaitu SHF, FA, A.Z, dan M.Z karena mampu menempelgambar sesuai warnanya. Pada kategori mulai berkembang (MB) ada 4 orang anak yaitu KE, FRS, GF dan NVL karena sudah mampu menempel gambar sesuai warnanya tetapi masih dengan bantuan guru. Pada kategori belum berkembang (BB) terdapat 8 orang anak yaitu IN, NL, INY, HK, AML, KM, AQ dan HF Karena sama sekali tidak mampu menempel gambar sesuai warna pada saat melakukan kegiatan kolase gambar topi.

- Pada indikator menempel dengan mengikuti garis pola. Pada kategori berkembang (B) dari 16 orang anak, ada 6 orang anak yaitu SHF, FA, GF, A.Z, M.Z dan NVL karena mampu menempel dengan mengikuti sesuai garis pola. Pada kategori mulai berkembang (MB) ada 3 orang anak yaitu IN, KE dan FRS karena sudah mampu menempel dengan mengikuti garis pola tetapi masih dalam bantuan guru. Pada kategori belum berkembang (BB) ada 7 orang anak yaitu NL, INY, HK, AML, $\mathrm{KM}, \mathrm{AQ}$, dan HF karena sama sekali tidak mampu menempel dengan mengikuti garis pola.

- Pada indikator menempel sesuai bentuk pola gambar. Pada kategori berkembang (B) dari 16 orang anak, ada 3 orang anak yaitu SHF, FA dan A.Z karena menempel sesuai bentuk pola gambar. Pada kategori mulai berkembang (MB) ada 4 orang anak yaitu IN, KE, M.Z, dan NVL karena sudah mampu menempel sesuai bentuk pola gambar tetapi masih dalam bantuan guru . Pada kategori belum berkembang (BB) ada 9 orang anak yaitu NL, INY, HK, AML, KM, AQ dan HF karena sama sekali tidak mampu menempel sesuai bentuk pola gambar.

- Pada indikator menempel gambar pola bangunan yang belum lengkap. Pada kategori berkembang (B) dari 16 orang anak, ada 3 orang anak yaitu SHF, A.Z dan M.Z karena mampu menempel gambar pola bangunan yang belum lengkap. Pada kategori mulai berkembang (MB) ada 5 orang anak yaitu IN, FA, KE, FRS, dan GF karena sudah mampu menempel gambar pola bangunan yang belum lengkap tetapi masih dalam bantuan guru . Pada kategori belum berkembang (BB) ada 8 orang anak yaitu, IN, INY, HK, AML, KM, AQ, NVL dan HF karena sama sekali tidak mampu Menempel gambar pola bangunan yang belum lengkap.

\section{Hasil Refleksi}

a. Hasil Refleksi Siklus I

Dari hasil penelitian tentang pembelajaran kegiatan kolase yang terjadi selama proses pembelajaran proses siklus 1 masih banyak anak dalam kategori belum berkembang 
dalam meningkatkan kecerdasan visual spasial anak, hal ini sesuai dengan pengamatan melalui lembar observasi yang menunjukan hasil pencapaian belum maksimal, maka refleksi yang ditemukan adalah pada perencanaan, umumnya sudah baik namun perlu di persiapkan lebih baik lagi, seperti cara guru dalam memberikan penjelasan tentanag langkah-langkah kegiatan kolase yang berbasis saintifik yang akan dilaksanakan sesuai dengan RPPH yang telah disusun untuk pedoman dalam kegiatan pembelajaran. Pada pelaksanaan, secara keseluruhan sudah mulai baik namun guru perlu menjelaskan dan memperkenalkan kepada anak terlebih dahulu contoh kolase sehingga dalam kegiatan pembelajaran nantinya anak mampu berpendapat.

Berdasarkan analisis dan refleksi diatas dapat mengacu kepada indikator keberhasilan, maka dapat di simpulkan bahwa pembelajaran melalui kegiatan kolase yang berbasis saintifik masih belum berhasil oleh karena itu pembelajaran melalui kegiatan kolase berbasis saintifik masih perlu di perbaharui dengan kegiatan pembelajaran yang baru pada tindakan siklus II dengan beberapa penyempurnaan pada perencanaan, guru perlu memberikan penjelasan yang dapat di pahami anak tentang bentuk kegiatan yang akan di laksanakan serta memberikan pemahaman kepada anak cara pembelajaran yang benar agar anak bisa menyampaikan pengalaman sendiri secara sederhana dengan benar yang lebih mudah di mengerti oleh anak didik. Pada pelaksanaan, jelaskan kepada anak langkahlangkah kegiatan kolase berbasis saintifikdengan lebih jelas kemudian memberikan contoh cara pembelajaran yang benar.

b. Hasil Refleksi Siklus II

Dari hasil penelitian tentang kecerdasan visual spasial anak yang terjadi selama proses pembelajaran pada siklus II Menunjjukan sudah banyak anak dalam kategori berkembang dalam meningkatkan kecerdasan visual spasial, hal ini sesuai dengan pengamatan lembar observasi yang menunnjukan hasil pencapaian sudah maksimal, maka refleksi yang ditemukan pada proses perencanaan yang telah dilakukan pada siklus II sudah berjalan baik, seluruh rancangan awal telah terlaksan. Berdasarkan hasil observasi pelaksanaan siklus II secara umum pelaksanaan tindakan siklus II sudah terlaksana dalam arti semua kegiatan peningkatan kecerdasan visual spasial anak sudah tercapai dengan baik. Pada siklus II terlihat adanya peningkatan dan perubahan tentang kemampuan guru dan anak dalam kegiatan kolase berbasis saintifik serta penguasaan anak dalam kegiatan kolase. perkembangan pada anak dari siklus 1 kategori berkembang (B) masih berada pada 12,8 $\%$ sedangkan pada siklus 2 telah mengalami peningkatan dari siklus 1 yaitu pada kategori berkembang (B) telah mencapai $87,1 \%$ sehingga penelitian pada siklus II ini telah dikatakan berhasil karena telah mencapai standar pencapaian yang telah di tetapkan.

Kecerdasan visual spasial adalah kepekaan pada garis, warna, bentuk, ruang, keseimbangan, bayangan, harmoni, pola. Dalam meningkatkan kecerdasan visual spasial anak maka digunakan kegiatan kolase yang berbasis saintifik. Nurhadiat (2005: 8) mengemukakan bahwa kolase adalah kegiatan membuat gambar dengan cara menempelkan benda tipis dan lebar setelah dibentuk terlebih dahulu dari pendapat tersebut dapat disimpulkan bahwa Kolase adalah sebuah karya seni dengan cara menempel berbagai macan bahan, seperti kertas, kertas koran, foto, pita atau benda lainnya yang ditempelkan pada pola gambar yang ada sedangkan pendekatan saintifik berdasarkan teori 
Dyer menurut Sani (2015) pembelajaran memiliki empat komponen proses pembelajaran antara lain : 1) Mengamati; 2) Menanya; 3) Mencoba/ mengumpulkan informasi; 4) manalar/ asosiasi, membentuk jejaring (melakukan komunikasi).

Melalui kegiatan kolase berbasis saintifik maka kecerdasan visual spasial anak akan meningkat. Hal ini terbukti dengan penelitian yang dilakukan yang terdiri dari siklus I sebanyak 2 kali pertemuan dan siklus II 2 kali pertemuan. Data tersebut merupakan data kualitatif yang di peroleh dari format observasi pada setiap kegiatan menggunakan kegiatan kolase yang dilaksanakan. Data tersebut dikumpulkan selama proses belajar mengajar berlangsung yang merupakan pelaksanakan tindakan dalam upaya pencapaian kecerdasan visual spasial.

Penelitian ini dilakukan dua siklus yakni siklus I dan siklus II pada setiap siklus anak diberikan kegiatan dalam bentuk lembar kerja. Hal ini untuk melihat perubahan dari kecerdasan visual spasial yang menjadi sasaran dalam penelitian ini. Pada siklus II anak sudah meningkat ini dapat dilihat pada indikator menempel gambar sesuai warna, menempel dengan mengikuti garis pola, menempel sesuai bentuk pola gambar dan menempel gambar pada bangunan yang belum lengkap pada kategori berkembang terdapat $87,1 \%$ Hasil tersebut menandakan bahwa kecerdasan visual spasial anak sudah meningkat dan telah mencapai standar pencapaian yang telah di tetapkan. Sehingga kegiatan kolase berbasis saintifik dalam cocok dalam peningkatkan kecerdasan visual spasial anak usia dini.

\section{KESIMPULAN}

Berdasarkan penelitian yang telah di lakukan dapat disimpulkan bahwa kecerdasan visual spasial melalui kegiatan kolase berbasis saintifik mengalami peningkatan yang dapat dilihat dari hasil panelitian siklus I dan siklus II dimana pada kategori baik pada siklus I dapat meningkat pada siklus II dengan capaian di atas indikator keberhasilan sehingga dari hasil perbandingan tersebut dapat dikatakan bahwa penggunaan kolase berbasis saintifik dapat meningkatkan kecerdasan visual spasial anak pada kelompok B1 Taman Kanak-kanak Aisyiyah Maccini Tengah Kota Makassar.

\section{DAFTAR PUSTAKA}

Arikunto, Suharsimi. Dkk. 2010. Penelitian Tindakan Kelas . Jakarta: Bumi Aksara

Asmani, J. M. 2015. Panduan Praktis Manejemen Mutu Guru Paud. Yogyakarta: DIVA press.

Bugin, Burhan. (2007). Penelitian Kualitatif. Jakarta: Kencana

Devi,F.P.2014. Peningkatan Kreativitas Melalui Kolase. Jurnal Pendidikan Anak, (Online), Vol.4 No 1, http://eprints.uny.ac.id/id/eprint/13449 , ( 21 April 2016).

Fuller, C. 2007. Maksimal Potensi Belajar Anak Anda . colorado Springs: Pion press.

Gardner,H. 1993. Frames Of Mind The Theory Of Multiple Intelegenies. New York: Basic Book

Iskandar. 2012. Penelitian Tindakan Kelas. Jakarta: Referensi 
Kementerian Pendidikan dan Kebudayaan. 2013. Konsep Pendekatan Scientific. Jakarta: Depertemen Pendidikan dan kebubayaan.

Nurhadiat,D.2005. Kerajinan tangan dan kesenian untuk sekolah dasar kelas 6. Jakarta:Grasindo.

Mulyasa, H.E. 2009. Praktik Penilitian Tindakan Kelas. Bandung: PT Remaja Rosdakarya.

Rodhliyah, S., \& N.Awangga, S. (2007). Tes Kecerdasan Visual Spasial .Yogyakarta: Palmall.

Riyanto, Y. 2009. Paradigma Baru Pembelajaran. Jakarta: Kencana.

Sani, R. A. 2015. Pembelajaran Saintifik untuk Implementasi kurikulum 2013. Jakarta: Bumi Aksara.

Sari,E.K. 2012. Peningkatan Perkembangan Motorik Halus Anak Melalui Kegiatan Kolase Dari Bahan Bekas. Jurnal Pesona PAUD, (Online), vol.1 No 1, http://ejournal.unp.ac.id/index.php/paud/article/download/1615/1389.

Subianto, P. 2004. Mendidik dengan Hati. Jakarta: Gramedia.

Sujiono, Y. N. 2009. Konsep Dasar Pendididkan Anak Usia Dini. Jakarta: Indeks.

Suminah, E. Dkk. 2015. Pedoman Penilaian Pembelajaran Pendidikan Anak Usia Dini. Jakarta : Direktorat Pembinaan Pendidikan Anak Usia Dini Direktorat Jendral Pendidikan Anak Usia Dini Dan Pendidikan Masyarakat Kementrian Pendidikan Dan Kebudayaan.

Triharso, A. 20 13. Permainan Kreatif \& Edukatif untuk Anak Usia Dini. Yogyakarta: Penerbit Andi.

Undang-undang Republik Indonesia Nomor 20 Tahun 2003 tentang sistem pendididkan Nasional, (online), http://kemenag.go.id/file/dokumen/UU2003.pdf,

Veronika H, \& Mesra. 2012. Penerapan Metode Demonstrasi Untuk Meningkatkan hasil Belajar Teknik Kolase Melalui kerajinan tangan dalam Mata Pelajaran SBK. Jurnal Usia Dini, (online), Vol.3 No.1, http://jurnal.unimed.ac.id/ 2012/ index.php/ gorga/article/download/176/67.

Yaumi, M., \& Ibrahim, N. 2013. Pembelajaran berbasis Kecerdasan Jamak. Jakarta: Kencana. 